Article

\title{
Development of Functional High-Protein Organic Bars with the Addition of Whey Protein Concentrate and Bioactive Ingredients
}

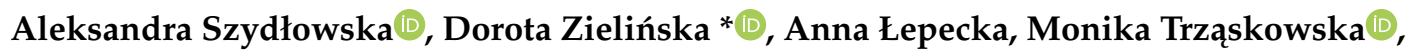 \\ Katarzyna Neffe-Skocińska and Danuta Kołożyn-Krajewska \\ Institute of Human Nutrition Sciences, Warsaw University of Life Sciences (WULS), 02776 Warszawa, Poland; \\ aleksandra_szydlowska@sggw.edu.pl (A.S.); anna_lepecka@sggw.edu.pl (A.Ł.); \\ monika_trzaskowska@sggw.edu.pl (M.T.); katarzyna_neffe_skocinska@sggw.edu.pl (K.N.-S.); \\ danuta_kolozyn_krajewska@sggw.edu.pl (D.K.-K.) \\ * Correspondence: dorota_zielinska@sggw.edu.pl; Tel.: +48-225-937-065; Fax: +48-225-937-068
}

Received: 10 July 2020; Accepted: 31 August 2020; Published: 3 September 2020

check for updates

\begin{abstract}
The study aimed to develop the high-protein bars using organic ingredients such as whey protein concentrate (WPC), prebiotic-inulin, as well as pro-health additives (dried fruits, cereals, and nuts). The physicochemical, microbiological, sensory, and consumer evaluation of ingredients and final products were made. The musli $(\mathrm{M})$, pumpkin $(\mathrm{P})$, and coconut $(\mathrm{C})$ bars were developed including three different flavors for each bar. The novel products were found to be a good source of protein and fiber. The $\mathrm{M}$ and $\mathrm{P} 3 \mathrm{bar}$ samples contained $>10 \mathrm{~g}$ of fiber $/ 100 \mathrm{~g}$ of product. The $\mathrm{M}$ and $\mathrm{C}$ bars contained over $20 \mathrm{~g} / 100 \mathrm{~g}$ proteins in total, while $\mathrm{P}$ bars contained 17.3-19.1 g/100 g of protein. The antioxidant activity of bars was proportional to the fruit content. The water activity was varied (0.63-0.74), while $\mathrm{pH}$ value ranged from 6.3 to 7.0. Microbiological quality of ingredients and bars were good, though in $\mathrm{M}$ and $\mathrm{P}$ bars, the presence of Bacillus cereus was found. The $\mathrm{C}$ bars found the highest marks of the overall quality. The newly developed high-protein products can be used in rational nutrition of a wide group of people who are health-conscious.
\end{abstract}

Keywords: whey protein concentrate (WPC); organic foods; high-protein bar; microbiological quality; sensory quality; consumer

\section{Introduction}

The modern lifestyle has led to significant changes in the dietary habits of people. Rapid urbanization, popularization of healthy food consumption habits, and food convenience have largely impacted the development of the global meal replacement products market. Often full meals are replaced with food known as "meal replacement", which includes substitutes for a wholesome dish in the form of a snack, bar, powder for making a drink or soup [1]. The global market size of meal replacement products was estimated at USD 15.1 billion in 2016 and is expected to reach USD 20.6 billion by 2021 [2]. Meal replacement products should provide about 300 calories per serving and supply $100 \%$ of the recommended daily intake for at least 12 essential vitamins and minerals, 8 to $10 \mathrm{~g}$ of protein (25-50\% of total energy in a product) [3]. Regulation (EC) No 1924/2006 [4] on nutrition and health claims made on foods indicate that a claim that food is high in protein may only be made where at least $20 \%$ of the energy value of the food is provided by protein.

One of the fastest-growing product groups on the market is high-protein bars. These products contain more proteins ( $>20 \mathrm{~g}$ of protein per serving) and fiber, have low carbohydrate and sodium content, and contain vitamins, minerals, and antioxidants. High-protein bars are especially dedicated 
to consumers who are physically active and health-conscious [5]. However, a growing group of consumers expresses interest in incorporating more protein into their diet. Some of them do not have enough time to prepare conventional meal and want a quick snack that will stop them from feeling hungry, while others are overweight and think that eating a bar instead of a meal will help them with weight control $[1,6]$. Indeed, the high-protein meal replacement diet may be an effective and safe strategy for weight loss in overweight and obesity, and thus may be important for the prevention of dyslipidemia and diabetes [7]. The high-protein bars production should include use of excellent raw materials that bring biologically active substances, i.e., the basic nutrients, as well as non-nutritive compounds naturally occurring in the raw material or in the product subjected to the technological process that affects the physiological and metabolic functions of the body [8].

Based on some evidence, organic food products are considered to have higher nutritional value compared to conventional ones. Organic plant raw materials contain fewer nitrates and pesticide residues, but more dry matter, phenolic compounds and polyphenols, vitamin $C$, total sugars, certain mineral components, and essential amino acids, but less $\beta$-carotene [9]. Moreover, the organic production is always certified according to rigorous standards, and this should be a guarantee that transparency on the food chain is ensured $[10,11]$.

Over the last few decades, it has been also observed that the organic food market has grown rapidly. Regular consumers of organic food are health-conscious, physically active females, in the higher brackets of education and income [12]. Health and ethics/environmental concerns, as well as weight-related motives, are important drivers of food choices in organic food consumers [13,14]. Organic meal replacement foodstuff could be a good solution for this group of consumers.

The producer of high-protein bars faces many challenges. First of all, the ingredients must meet specific nutritional requirements and the final product should meet consumers' need for convenience and health benefits. The novelty of the present project consists of combining the functionality of the product intended for physically active people (high protein content) with its high nutritional value, safety, and acceptable, high sensory quality. Although numerous formulations have been made until now, for some of the bars on the market acceptable taste is not yet achieved. In processing new products, it is crucial to optimize both sensory and functional properties of the product for proper acceptability and exceptional quality. The assumption was to get bars also with high nutritional value. Therefore, the aim of the study was to develop high-protein bars using organic ingredients such as whey protein concentrate (WPC), prebiotic-inulin, and pro-health additives (dried fruits, cereals, and nuts). The comparative analysis of physicochemical, microbiological, and sensory quality of raw material and final products were made. The results of this study are expected to benefit the industry, as well as the growing needs of consumers.

\section{Materials and Methods}

\subsection{Materials}

The organic plant-origin material (cereals, dried fruits, nuts, chocolate, and others) as well as WPC was provided by SYMBIO Poland S.A. (Table 1).

Three types of organic bars were designed: musli $(\mathrm{M})$ bar, pumpkin $(\mathrm{P})$ bar, and coconut $(\mathrm{C})$ bar. The $\mathrm{M}$ bars contained coconut oil and flakes, oat flakes, sesame, dried dates, and peanut butter. The P bars consisted of pumpkin seeds, spelt flakes, coconut oil, and flakes, as well as dried dates, inulin, and chocolate. The $\mathrm{C}$ bars contained coconut flakes, oil and flour, sugar, chocolate, and jam. The organic WPC was added to all bars. The researched material consisted of 9 bars (3 types of each), marked, respectively, by the following symbols: musli bars (M1—with raisins, M2 - with nuts, M3 - with goji berries), pumpkin bars (P1-basic, P2 - with nuts, P3 - with cocoa), and coconut bars (C1-with currant jam, C2-with cherry jam, C3-with chokecherry jam). The composition of bars is presented in Table 1. 
Table 1. Composition of high-protein bars.

\begin{tabular}{|c|c|c|c|c|c|c|c|c|c|}
\hline \multirow{3}{*}{ Ingredients } & \multicolumn{9}{|c|}{ Bar Symbol } \\
\hline & M1 & M2 & M3 & P1 & P2 & P3 & $\mathrm{C} 1$ & $\mathrm{C} 2$ & $\mathrm{C} 3$ \\
\hline & \multicolumn{9}{|c|}{ The Amount of Ingredient [g] } \\
\hline $\begin{array}{l}\text { Whey protein } \\
\text { concentrate }\end{array}$ & 15.6 & 15.6 & 15.6 & 12.0 & 12.0 & 12.0 & 24.7 & 24.7 & 24.7 \\
\hline Coconut flakes & 4.0 & 4.0 & 4.0 & 4.9 & 5.2 & 2.9 & 8.2 & 8.2 & 8.2 \\
\hline Coconut flour & - & - & - & - & - & - & 11.0 & 11.0 & 11.0 \\
\hline Coconut oil & 7.0 & 7.0 & 6.8 & 3.9 & 3.9 & 3.9 & 8.2 & 8.2 & 8.2 \\
\hline Pumpkin seeds & - & - & - & 19.4 & 10.1 & 19.4 & - & - & - \\
\hline Oat flakes & 21.4 & 21.4 & 20.3 & - & - & - & - & - & - \\
\hline Spelt flakes & - & - & - & 19.1 & 10.1 & 19.1 & - & - & - \\
\hline Sesame & 7.0 & 5.6 & 6.1 & - & - & - & - & - & - \\
\hline Dried dates & 14.0 & 14.0 & 13.5 & 19.4 & 20.3 & 19.4 & - & - & - \\
\hline Raisins & 10.0 & - & - & - & - & - & - & - & - \\
\hline Goji berries & - & - & 6.7 & - & - & - & - & - & - \\
\hline Dried cherries & - & - & 6.7 & - & - & - & - & - & - \\
\hline Hazelnuts & - & 5.7 & - & - & 20.3 & - & - & - & - \\
\hline Walnuts & - & 5.7 & - & - & - & - & - & - & - \\
\hline Peanut butter & 14.0 & 14.0 & 13.3 & - & - & - & - & - & - \\
\hline Currant jam & - & - & - & - & - & - & 12.3 & - & - \\
\hline Cherry jam & - & - & - & - & - & - & - & 12.3 & - \\
\hline Chokeberry jam & - & - & - & - & - & - & - & - & 12.3 \\
\hline Cocoa & - & - & - & - & - & 1.9 & - & - & - \\
\hline Chocolate & - & - & - & 9.7 & 10.0 & 9.8 & 13.7 & 13.7 & 13.7 \\
\hline Inulin & - & - & - & 1.9 & 2.0 & 1.9 & - & - & - \\
\hline Sugar cane & - & - & - & - & - & - & 8.2 & 8.2 & 8.2 \\
\hline Water & 7.0 & 7.0 & 7.0 & 9.7 & 6.1 & 9.7 & 13.7 & 13.7 & 13.7 \\
\hline Summary & 100.0 & 100.0 & 100.0 & 100.0 & 100.0 & 100.0 & 100.0 & 100.0 & 100.0 \\
\hline
\end{tabular}

High-protein bars were made by crushing and mixing of ingredients. The dried dates were soaked in hot water for $30 \mathrm{~min}$ before use and then shredded into a smooth mass. All ingredients were combined, mixed, and the mass was shaped in bars. Chocolate ( $70 \%$ of cacao) was liquefied and used to wrap the bars. Formed bars were stored at a temperature of $4{ }^{\circ} \mathrm{C}$ for $10 \mathrm{~h}$ and then used for analysis.

The production yield $(\mathrm{Y})$ was calculated by dividing the weight of the bar after cooling by the mass of the bar components used for production and multiplying by $100 \%$, as follows:

$$
Y=\frac{\text { mass of final product }[g]}{\text { sum of mass of ingredients }[g]} \times 100 \%
$$

\subsection{Methods}

\subsubsection{Physicochemical Quality of Newly Developed High-Protein Bars}

Proximate Composition Analysis and Determining Caloric Value

The formulated bars were crushed in mortar and pestle prior to analysis. The proximate analysis (moisture, ash, crude lipids, protein, crude fiber) were determined [15,16]. Crude carbohydrate was determined by difference from the total protein, lipids, moisture, ash, and crude fiber contents. Caloric values were computed using the Atwater general factor system: carbohydrate (4 kcal/g), lipid $(9 \mathrm{kcal} / \mathrm{g})$, and protein $(4 \mathrm{kcal} / \mathrm{g})[17]$. 


\section{Amino Acid Composition}

The analysis was based on the method of sample hydrolysis and the analysis of the individual amino acids using HPLC (High-Performance Liquid Chromatography) with Post Column Derivatization. To determine the total amino acids, two methods were required, including the 994.12 (based on [15]), but in addition, the sulfur-containing amino acids (such as methionine) require a pre-oxidation step [16].

\section{Fatty Acid Composition}

The fatty acids were carried out in methyl esters (FAME) [18]. FAME was split by gas chromatography (GC) using the Varian CG 3900 (Walnut Creek, CA, USA) chromatograph with a flame ionization detector (FID) [19].

\section{Antioxidant Activity}

The antioxidant capacity of the samples (bars ingredients and bars) was investigated through the evaluation of the free radical-scavenging effect on the DPPH (1,1-diphenyl-2-picrylhydrazyl, Sigma Aldrich, Darmstadt, Germany) radical, based on the method described by Brand-Williams et al. [20] and Alothman et al. [21]. DPPH solution was prepared by dissolving $0.012 \mathrm{~g}$ DPPH $(\mathrm{M}=394.32 \mathrm{~g} / \mathrm{mol})$ in $100 \mathrm{~mL}$ of ethanol. The prepared solution was kept in the dark. Extracts were prepared by mixing $25 \mathrm{~g}$ of crushed samples of bars or bar ingredients with $100 \mathrm{~mL}$ of ethanol. Mixtures were extracted with shaking and kept in the dark for $20 \mathrm{~h}$ at room temperature, then filtered.

The A0 absorbance was measured by adding $0.2 \mathrm{~mL}$ of a DPPH solution to $0.8 \mathrm{~mL}$ of ethanol. The tested samples contained $0.2 \mathrm{~mL}$ of a DPPH solution and $0.6 \mathrm{~mL}$ of ethanol and $0.2 \mathrm{~mL}$ of the extract being tested. The absorbance (A) was measured $30 \mathrm{~min}$ after the reaction was initiated. Each measurement was performed three times and the average absorbance (Ar) value for the given solution with standard deviation was calculated.

The absorbance of the resulting solution was measured at $517 \mathrm{~nm}$ against a blank of ethanol without DPPH using a UV-visible spectrophotometer GenesysTM 20 (Thermo Scientific, Waltham, MA, USA). Results were expressed as a percentage of inhibition of the DPPH radical, which was calculated according to the following equation:

$$
\% \text { inhibition of DPPH }=100 \times(\mathrm{A} 0-\mathrm{Ar}) / \mathrm{A} 0
$$

\section{Measurement of $\mathrm{pH}$}

The $\mathrm{pH}$ value was measured 3 times of each sample using the CP-511 $\mathrm{pH}$ meter (Elmetron, Zabrze, Poland) [22]. The results were presented with an accuracy of 0.001 with standard deviations.

\section{Water Activity}

Measurement of water activity of bar samples was carried out with the water activity meter-AquaLab Series 4TE (Decagon Devices, Pullman, WA, USA) using a photoelectric sensor by the dew point detection method. Samples weighing about $5 \mathrm{~g}$ were placed in the test container and then in the measuring chamber of the apparatus. For the final result of the water activity of the tested samples, the average value of 3 replicates was taken [23]. The results were presented with an accuracy of 0.01 with standard deviations.

\subsubsection{Microbiological Quality}

In the study, microbiological quality of developed bars, as well as bars ingredients, were investigated. Bars were evaluated immediately after production (time 0 ) and after 4 weeks of storage at $4{ }^{\circ} \mathrm{C}$ and at $37^{\circ} \mathrm{C}$. Thermostat assay was used to accelerate the microbiological growth of potential pathogens, thus safety of tested bars could be evaluated. Briefly, bars ingredients and bars samples 
( $25 \mathrm{~g}$ ) were transferred to $225 \mathrm{~mL}$ peptone water (LabM, Heywood, UK) and homogenized, serially diluted in sterile peptone water, and surface spread on duplicate plates with the appropriate medium.

Nutrient agar (Biokar Diagnostic, Noack, Poland) was used for the enumeration of total viable counts. The plates were incubated at $30^{\circ} \mathrm{C}$ for $72 \mathrm{~h}$ [24]. Enterobacteriaceae family was enumerated on MacConkey agar (LabM) according to Reference [25]. The plates were incubated at $37^{\circ} \mathrm{C}$ for $24 \mathrm{~h}$. Chloramphenicol Glucose Agar (Biokar Diagnostic) and incubation at $25^{\circ} \mathrm{C}$ for $120 \mathrm{~h}$ were used for enumeration of yeast and molds [26,27].

Moreover, some pathogens and spoilage microflora were investigated. Enumeration of Escherichia coli using TBX agar (LabM) was made [28]. Bacillus cereus was investigated on agar PEMBA (LabM) [29]. The presence of Salmonella spp. was checked on XLD agar (LabM) [30].

\subsubsection{Sensory Quality and Consumer Acceptance}

\section{Sensory Quality}

The sensory evaluation of products was conducted using the Quantitative Descriptive Profile (QDP) method [31]. The experts' team selected the sensory descriptors (characteristic attributes of odor, texture, and flavor). Separate sensory descriptors were defined for each tested bar (Supplementary Materials, Table S1). Based on the quality characteristics, the sensory panel indicated an overall sensory quality (low-high) for each sample. The task of the assessors was to determine the intensity of each of quality features and to put their assessment on unstructured, $10 \mathrm{~cm}$ graphic scale (contractual units, 0-10 c.u.). Bars were portioned into equal weight (approximately $20 \mathrm{~g}$ ) and placed in plastic boxes $(125 \mathrm{~mL})$ covered with lids and kept in at room temperature $\left(22 \pm 1^{\circ} \mathrm{C}\right)$ for $30 \mathrm{~min}$ before analysis. All samples were coded with three-digit codes and passed in random order. Each time a team of 8 employees of the Department of Food Gastronomy and Food Hygiene at Warsaw University of Life Sciences (WULS) were conducted the assessment. The members of the evaluation team were trained in the methodology of performed analyzes and examined in terms of sensory sensitivity. The evaluation was carried out in two sessions in purpose to obtain 16 replications.

\section{Consumer Assessment}

The assessment was attended by people who agreed to participate in the study and declared that they are consumers of high-protein bars. The study was conducted with a convenience sample of 60 people ( 44 women and 16 men) aged between 19 and 65 years (mean 29 years), inhabitants of Warsaw, Poland. The consumers received a sample of the product (C3-with chokeberry jam) along with the questionnaire, which is placed in Supplementary Materials, Table S2. Their task was to assign the appropriate degree of desirability using the hedonic 9-point scale [32]. Consumers were also asked to fill in a short questionnaire and answer the questions regarding desirableness of the bar, whether they buy organic food, do they know the offer of protein products, how often they buy protein products, play sports, pay attention to their diet, or purchase such a product if it would be available for sale and about a price that they would pay for such a product.

\subsubsection{Statistical Analysis}

Statistical significance was recognized when $p<0.05$. One-way analysis of variance (ANOVA) with a linear model, as well as LSD test, was applied to analyze the data. Additionally, the Principal Component Analysis (PCA) was used to assess the results of the QDP. Tests were conducted using Statistica 13 (StatSoft Inc., Tulsa, OK, USA). 


\section{Results and Discussion}

\subsection{Physicochemical Quality of Newly Developed High-Protein Bars}

\subsubsection{Proximate Composition, Amino Acids, and Fatty Acids Analysis}

The type of products affected proximate composition and caloric value of tested bars. The results for proximate composition analysis of developed bars are presented in Table 2 . The highest $(p<0.05)$ caloric value (above $400 \mathrm{kcal}$ per $100 \mathrm{~g}$ of product) as well the highest carbohydrates (27.3-28.8 g) and crude lipids (22.4-23.0 g) content was recorded in the case of P bars. These bars contained higher amounts of dried dates, pumpkin seeds, and spelt flakes in comparison to other bars. Fat content of pumpkin seeds can be even $49 \%$ [33].

The total caloric value of $\mathrm{M}$ and $\mathrm{C}$ bars was below $400 \mathrm{kcal}$ per $100 \mathrm{~g}$ of product, except C3 sample. Furthermore, the carbohydrate content ranges from 23.4 to $24.3 \mathrm{~g}$ in case of C bars and 24.6-26.9 $\mathrm{g}$ in case of $\mathrm{M}$ bars. In turn, lipid content was 21.1-22.0 $\mathrm{g}$ in the case of $\mathrm{C}$ bars, and 19.1-19.9 $\mathrm{g}$ in the case of $\mathrm{M}$ bars. No sucrose additive was provided in the recipes of all the tested bars. To improve consistency and to obtain a sweet taste, the inulin additive was used, which at the same time enriched the products into fiber. In the production of bars, dried fruits are also often used instead of sucrose [8].

Fat and fatty acids are essential nutrients, but the type and amount of fat consumed in terms of disease prevention should not be neglected. In the investigated bars, the sum of saturated fatty acids (SFA) was found at 9\% to 19\% (Table 3). The highest level of these compounds in total (18.4-19.0\%) was reported in the $\mathrm{C}$ bars due to the addition of chocolate and coconut oil. However, the sum of trans-isomers of fatty acids (TFA) in all products was $<0.1 \%$, which is beneficial given the need to reduce their consumption because of harmful impact on health. This low content is due to the lack of such bar ingredients as industrially hardened vegetable oils that are incorporated into bakery fats or margarine. On the other hand, the highest unsaturated FAsomega-6 and omega-9 were noted due to the content of the seed and nuts products, and was higher in the case of $\mathrm{P}$ and $\mathrm{M}$ bars $(p<0.05)$, in contrast to $C$ bar samples. Moreover, the quantitative advantage of omega- 6 acids $(0.3-5.0 \%)$ was recorded over omega-3 acids $(<0.1 \%)$ in all bar samples. Unsaturated FAs were represented in the products mainly by cis-configuration acids, monounsaturated fatty acids (MUFA). It was found that vegetable oils are a good source of oleic acid, in addition to olive oil [34,35]. Snack bars with a high content of essential fatty acids are generally those that contain crop seeds and vegetable oils (canola, soybeans, corn, and sunflower oils); these are the major sources of linoleic acid (LA, C18:2) but with a low proportion of $\alpha$-linolenic acid (ALA, C18:3) [36]. In this context, the most favorable were $\mathrm{M}$ and $\mathrm{P}$ bars.

The WPC addition varied depending on the type of bars due to other ingredients, which determined the consistency of final products (Table 1). To prepare C bars, $24.7 \mathrm{~g}$ of WPC/100 $\mathrm{g}$ of all ingredients was used, whereas M and P bars ingredients contained only $15.6 \mathrm{~g}$ and $12.0 \mathrm{~g}$ of WPC/100 $\mathrm{g}$ of all ingredients, respectively. In purpose to increase the level of protein concentration, other rich protein ingredients were added, i.e., nuts, seeds, sesame. High-protein bars should include a high level of protein $(15-35 \% w / w)$ and other nutritionally beneficial ingredients [37]. The most popular sources of protein are whey protein isolate or whey protein concentrate [38]. Total protein content in tested organic WPC, which was used as an ingredient in newly developed organic bars, was found to be $80.09 \pm 0.19 \mathrm{~g} / 100 \mathrm{~g}$ of product (data not shown). The $\mathrm{M}$ and $\mathrm{C}$ bars contained over $20 \mathrm{~g} / 100 \mathrm{~g}$ proteins in total in comparison with $\mathrm{P}$ bars that contained less $(17.3-19.1 \mathrm{~g} / 100 \mathrm{~g})$ of protein $(p<0.05)$. The protein content of bars in the present study was similar to those designed by Veggi et al. [39].

The differences in the amount of protein added (Table 1) in relation to the amount of obtained protein in the final products (Table 2) may be due to the addition of other rich protein ingredients, production methods (grinding or soaking in hot water), as well as the efficiency of production. 
Table 2. Proximate chemical composition of high-protein bars.

\begin{tabular}{|c|c|c|c|c|c|c|c|c|c|}
\hline \multirow{2}{*}{ Fractions } & \multicolumn{9}{|c|}{ Bar Symbol } \\
\hline & M1 & M2 & M3 & P1 & P2 & P3 & $\mathrm{C} 1$ & $\mathrm{C} 2$ & $\mathrm{C} 3$ \\
\hline Total caloric value (kcal per $100 \mathrm{~g}$ ) & $388 \pm 0.12^{\mathrm{A}}$ & $386 \pm 0.07^{\mathrm{A}}$ & $396 \pm 0.05^{\mathrm{AB}}$ & $410 \pm 0.05^{\mathrm{D}}$ & $415 \pm 0.11^{\mathrm{D}}$ & $405 \pm 0.05^{\mathrm{C}}$ & $394 \pm 0.06^{\mathrm{AB}}$ & $388 \pm 0.05^{\mathrm{A}}$ & $403 \pm 0.11^{C}$ \\
\hline${ }^{*}$ Crude lipids $(\mathrm{g})$ & $19.1 \pm 0.03^{\mathrm{A}}$ & $19.9 \pm 0.01^{\mathrm{A}}$ & $19.7 \pm 0.01^{\mathrm{A}}$ & $23.0 \pm 0.01^{C}$ & $22.4 \pm 0.10^{\mathrm{C}}$ & $22.6 \pm 0.01^{C}$ & $22.0 \pm 0.01^{C}$ & $21.6 \pm 0.01 \mathrm{BC}$ & $21.1 \pm 0.01^{\text {B }}$ \\
\hline * Available carbohydrates (g) & $26.0 \pm 0.32^{B}$ & $24.6 \pm 0.21 \mathrm{AB}$ & $26.9 \pm 0.11$ BC & $28.8 \pm 0.14^{\mathrm{D}}$ & $28.8 \pm 0.08^{\mathrm{D}}$ & $27.3 \pm 0.23^{C}$ & $23.4 \pm 0.05^{\mathrm{A}}$ & $23.4 \pm 0.11^{\mathrm{A}}$ & $24.3 \pm 0.1 \mathrm{AB}$ \\
\hline${ }^{*}$ Crude fiber $(\mathrm{g})$ & $12.9 \pm 0.22^{\mathrm{D}}$ & $13.2 \pm 0.09^{\mathrm{D}}$ & $11.2 \pm 0.13^{C}$ & $8.9 \pm 0.11^{\text {В }}$ & $8.1 \pm 0.07 \mathrm{AB}$ & $10.6 \pm 0.05^{\mathrm{BC}}$ & $7.3 \pm 0.51^{\mathrm{A}}$ & $8.0 \pm 0.13 \mathrm{AB}$ & $7.4 \pm 0.09 \mathrm{~A}$ \\
\hline * Total Protein (g) & $21.3 \pm 0.38^{\mathrm{D}}$ & $20.4 \pm 0.14^{\mathrm{C}}$ & $20.7 \pm 0.40^{C}$ & $17.3 \pm 0.68^{\mathrm{A}}$ & $19.1 \pm 0.85^{\text {В }}$ & $18.9 \pm 0.32^{\mathrm{B}}$ & $21.1 \pm 0.11^{\mathrm{D}}$ & $20.9 \pm 0.06^{C D}$ & $21.3 \pm 0.57^{\mathrm{D}}$ \\
\hline${ }^{*}$ Ash $(\%)$ & $2.1 \pm 0.05^{\mathrm{A}}$ & $2.3 \pm 0.09 \mathrm{AB}$ & $2.1 \pm 0.11^{\mathrm{A}}$ & $2.3 \pm 0.04 \mathrm{AB}$ & $2.4 \pm 0.05^{\mathrm{B}}$ & $2.2 \pm 0.05 \mathrm{AB}$ & $2.2 \pm 0.06^{\mathrm{AB}}$ & $2.2 \pm 0.05 \mathrm{AB}$ & $2.2 \pm 0.13 \mathrm{AB}$ \\
\hline * Moisture (\%) & $18.6 \pm 0.22 \mathrm{AB}$ & $19.5 \pm 0.15^{\text {В }}$ & $18.0 \pm 0.08^{\mathrm{A}}$ & $19.7 \pm 0.11^{\text {В }}$ & $17.8 \pm 0.08^{\mathrm{A}}$ & $19.4 \pm 0.21^{\mathrm{B}}$ & $23.8 \pm 0.12^{C}$ & $25.8 \pm 0.09 \mathrm{CD}$ & $19.7 \pm 0.12^{\text {B }}$ \\
\hline
\end{tabular}

Explanatory: * on the $100 \mathrm{~g}$ dry weight basis of product; Values denoted by different superscripts in the same row differ significantly $(p<0.05)$.

Table 3. Fatty acid content (\%) of high-protein bars.

\begin{tabular}{|c|c|c|c|c|c|c|c|c|c|}
\hline \multirow{2}{*}{ Fatty Acids [\%] } & \multicolumn{9}{|c|}{ Bar Symbol } \\
\hline & M1 & M2 & M3 & P1 & P2 & P3 & $\mathrm{C} 1$ & $\mathrm{C} 2$ & $\mathrm{C} 3$ \\
\hline MUFA & $5.1 \pm 0.25^{\mathrm{B}}$ & $4.9 \pm 0.12^{B}$ & $5.1 \pm 0.15^{B}$ & $5.1 \pm 0.10^{B}$ & $6.2 \pm 0.10^{C}$ & $6.2 \pm 0.13^{C}$ & $3.2 \pm 0.09 \mathrm{~A}$ & $2.4 \pm 0.11^{\mathrm{A}}$ & $2.4 \pm 0.21^{\mathrm{A}}$ \\
\hline PUFA & $4.1 \pm 0.06^{\mathrm{B}}$ & $4.3 \pm 0.11^{\mathrm{B}}$ & $4.4 \pm 0.23^{\mathrm{B}}$ & $4.4 \pm 0.15^{\text {В }}$ & $5.0 \pm 0.13^{\mathrm{B}}$ & $4.6 \pm 0.10^{\mathrm{B}}$ & $0.4 \pm 0.09 \mathrm{~A}$ & $0.3 \pm 0.22^{\mathrm{A}}$ & $0.3 \pm 0.12^{\mathrm{A}}$ \\
\hline SFA & $9.0 \pm 0.12^{\mathrm{A}}$ & $10.8 \pm 0.09 \mathrm{AB}$ & $10.2 \pm 0.17 \mathrm{AB}$ & $10.2 \pm 0.12 \mathrm{AB}$ & $11.2 \pm 0.24^{B}$ & $11.8 \pm 0.10^{\mathrm{B}}$ & $18.8 \pm 0.18^{C}$ & $19.0 \pm 0.13^{C}$ & $18.4 \pm 0.11^{C}$ \\
\hline Omega-3 & $<0.1$ & $<0.1$ & $<0.1$ & $<0.1$ & $<0.1$ & $<0.1$ & $<0.1$ & $<0.1$ & $<0.1$ \\
\hline Omega-6 & $4.1 \pm 0.16^{\mathrm{B}}$ & $4.2 \pm 0.11^{\text {В }}$ & $4.3 \pm 0.08^{\text {B }}$ & $5.0 \pm 0.34^{C}$ & $5.0 \pm 0.27^{C}$ & $4.6 \pm 0.15^{\mathrm{BC}}$ & $0.4 \pm 0.14^{\mathrm{A}}$ & $0.3 \pm 0.13^{\mathrm{A}}$ & $0.3 \pm 0.10^{\mathrm{A}}$ \\
\hline Omega-9 & $5.0 \pm 0.23^{B}$ & $4.8 \pm 0.10^{B}$ & $5.0 \pm 0.10^{B}$ & $5.7 \pm 0.14^{\mathrm{BC}}$ & $6.0 \pm 0.09 \mathrm{BC}$ & $6.0 \pm 0.11 \mathrm{BC}$ & $3.2 \pm 0.21 \mathrm{~A}$ & $2.4 \pm 0.11^{\mathrm{A}}$ & $2.4 \pm 0.15^{\mathrm{A}}$ \\
\hline TFA & $<0.1$ & $<0.1$ & $<0.1$ & $<0.1$ & $<0.1$ & $<0.1$ & $<0.1$ & $<0.1$ & $<0.1$ \\
\hline
\end{tabular}

Explanatory: MUFA—monounsaturated fatty acids, PUFA—polyunsaturatedfatty acids, SFA—saturated fatty acids, TFA—trans fatty acids; Values denoted by different superscripts in the

same row differ significantly $(p<0.05)$ 
It was found that $\mathrm{M}$ bars were characterized by the highest production capacity (96-99\%), similarly, the $\mathrm{C}$ bars (80-82\%), whereas $\mathrm{P}$ bars were found to have the lowest production efficiency (in the range of 53-62\%) (Table 4). The reason for the low production capacity in the case of $\mathrm{P}$ bars was to grind parts of the bar ingredients (spelt, pumpkin, and coconut flakes), which resulted in a reduction in the weight of the final products. Weight losses of selected ingredients may also have affected the protein content of bars.

Table 4. Production yield and physicochemical properties of high-protein bars.

\begin{tabular}{ccccc}
\hline Bar Symbol & $\begin{array}{c}\text { Production Yield } \\
{[\%]}\end{array}$ & pH Value & $\begin{array}{c}\text { Water Activity } \\
\mathbf{( a}_{\mathbf{w}} \mathbf{)}\end{array}$ & $\begin{array}{c}\text { Antioxidant Activity } \\
{\left[\begin{array}{c}\text { \% Inhibition of DPPH] } \\
\text { In }\end{array}\right.}\end{array}$ \\
\hline M1 & $96.19 \pm 1.76^{\mathrm{A}}$ & $6.793 \pm 0.036^{\mathrm{A}}$ & $0.65 \pm 0.02^{\mathrm{A}}$ & $61.0 \pm 0.8^{\mathrm{A}}$ \\
M2 & $98.99 \pm 3.94^{\mathrm{A}}$ & $7.013 \pm 0.015^{\mathrm{B}}$ & $0.63 \pm 0.03^{\mathrm{A}}$ & $63.9 \pm 1.0^{\mathrm{B}}$ \\
M3 & $99.87 \pm 2.46^{\mathrm{A}}$ & $6.334 \pm 0.022^{\mathrm{C}}$ & $0.69 \pm 0.01^{\mathrm{B}}$ & $69.3^{\mathrm{C}} \pm 1.2^{\mathrm{C}}$ \\
\hline P1 & $53.82 \pm 4.02^{\mathrm{D}}$ & $6.948 \pm 0.061^{\mathrm{B}}$ & $0.63 \pm 0.00^{\mathrm{A}}$ & $54.1 \pm 1.1^{\mathrm{D}}$ \\
P2 & $59.38 \pm 3.26^{\mathrm{CD}}$ & $6.994 \pm 0.017^{\mathrm{B}}$ & $0.74 \pm 0.02^{\mathrm{C}}$ & $56.6 \pm 0.5^{\mathrm{D}}$ \\
P3 & $62.74 \pm 2.93^{\mathrm{C}}$ & $6.905 \pm 0.003^{\mathrm{B}}$ & $0.63 \pm 0.01^{\mathrm{A}}$ & $69.3 \pm 1.0^{\mathrm{C}}$ \\
\hline C1 & $81.90 \pm 3.08^{\mathrm{B}}$ & $6.897 \pm 0.025^{\mathrm{B}}$ & $0.73 \pm 0.02^{\mathrm{C}}$ & $77.1 \pm 0.6^{\mathrm{E}}$ \\
C2 & $80.08 \pm 2.86^{\mathrm{B}}$ & $6.926 \pm 0.011^{\mathrm{B}}$ & $0.71 \pm 0.01^{\mathrm{B}}$ & $76.1 \pm 1.1^{\mathrm{E}}$ \\
C3 & $81.52 \pm 2.44^{\mathrm{B}}$ & $6.945 \pm 0.014^{\mathrm{B}}$ & $0.73 \pm 0.01^{\mathrm{C}}$ & $75.2 \pm 0.9^{\mathrm{E}}$ \\
\hline
\end{tabular}

Explanatory: musli bars (M1—with raisins, M2—with nuts, M3—with goji berries), pumpkin bars (P1—basic, P2 - with nuts, P3 - with cocoa), and coconut bars (C1-with currant jam, C2 - with cherry jam, C3-with chokecherry jam); Values denoted by different superscripts in the same column differ significantly $(p<0.05)$.

On the other hand, the amino acid profile of tested WPC was found to be advantageous because it has a high content of essential amino acids: lysine, leucine, isoleucine, valine, and the presence of less arginine and histidine (Supplementary Materials, Table S3). Additionally, a high content of glutamic acid and aspartic acid was found (14.30 g and $8.41 \mathrm{~g}$ per $100 \mathrm{~g}$ of WPC, respectively). The $\mathrm{P}$ bars were the poorest in amino acid content, except high arginine concentration (especially in P1 and P2 samples), which was similar to $\mathrm{M}$ samples. It was also found that $\mathrm{M}$ bars were rich in standard amino acids like aspartic acid (>2.6 g/100 g), glutamic acid (>3.9 g/100 g), serine (>1.0 g/100 g), glycine $(>1.7 \mathrm{~g} / 100 \mathrm{~g})$, alanine $(>1.0 \mathrm{~g} / 100 \mathrm{~g})$, proline $(>1.1 \mathrm{~g} / 100 \mathrm{~g})$, cysteine $(>0.5 \mathrm{~g} / 100 \mathrm{~g})$ as well as some essential amino acids like histidine $(>0.46 \mathrm{~g} / 100 \mathrm{~g})$, threonine $(>1.0 \mathrm{~g} / 100 \mathrm{~g})$, and phenylalanine $(>0.78 \mathrm{~g} / 100 \mathrm{~g})$. In comparison, $\mathrm{C}$ bars were rich in essential amino acids like threonine $(>1.1 \mathrm{~g} / 100 \mathrm{~g}$ for C2 and C3), valine (>1.00 g/100 g), methionine (>0.4 g/100 g), isoleucine (>0.97 g/100 g), leucine $(>2.14 \mathrm{~g} / 100 \mathrm{~g})$, phenylalanine $(>0.75 \mathrm{~g} / 100 \mathrm{~g})$, and lysine $(>1.6 \mathrm{~g} / 100 \mathrm{~g})$.

Essential amino acids cannot be produced by the human body, therefore, they must be supplied in food. Amino acid composition of whey proteins is very similar to that of skeletal muscle, providing almost all of the amino acids in approximate proportion to their ratios in muscle. The abundance of leucine in whey is important because it plays a distinct role in protein metabolism and has been identified as a key signal in the translation initiation pathway of muscle protein synthesis. On the other hand, glutamine is a fuel for rapidly dividing cells and has been considered to be "conditionallyessential" during times of metabolic stress or illness. It is presumed that the composition of essential amino acids in foods that are a source of protein is a factor determining the ability to stimulate the anabolic processes of muscle tissue; therefore, all essential amino acids should be present in each meal in sufficient amounts to optimize the postprandial muscle protein synthesis process [40].

Incorporation of protein and fiber-rich sources in the diet will provide the fullness and fulfill the hunger as well as deliver the essential nutrients as per recommended daily intake. The protein-rich sources used for bars include oats, peanuts, soybean flour, soy flour or amaranth, and different varieties of beans [41-43]. In the nutrition, fiber plays a significant role in preventing obesity, diabetes, and cardiovascular disease [44]. In the present study, all tested bars contained dietary fiber above $7 \mathrm{~g}$ (Table 2) and can, therefore, be considered as products with a high content of that ingredient [4]. 
Most favorable in this case were M1, M2, M3, and P3 bar samples that contained even more than $10 \mathrm{~g}$ of fiber per $100 \mathrm{~g}$ of product, which could have been a result of oat flakes and inulin addition.

\subsubsection{Antioxidant Activity}

Plant products contain various antioxidants that protect against reactions involving already formed free radicals, including hydrophilic antioxidants: glutathione and vitamin C, hydrophobic antioxidants: vitamin E, carotenoids, xanthophylls, reduced coenzyme Q10 and anthocyanins, flavonoids, phytoestrogens [45]. The highest antioxidant activity referred to as \% DPPH inhibition was noted in the case of organic goji berries (98.1\%) and dried cherries (97.6\%) (Table 5). Furthermore, organic cocoa, chocolate, dried dates, hazelnuts, and cherry jam demonstrated high antioxidant activity (above $80 \%$ ). It was also found that the evaluated bar samples were characterized by a high scavenging capacity of DPPH free radicals (Table 4). The highest values $(p<0.05)$ of antioxidant activity were observed in $C$ bars $(75.2-77.1 \%)$. The $M$ bars showed moderate activity (61.0-69.3\%), but the samples differ significantly $(p<0.05)$. The highest antioxidant activity was observed in the case of the M3 bar-with the addition of goji berries. The P bars were characterized by average antioxidant properties (54.1-69.3\%) inhibition of DPPH. The antioxidant abilities of the tested products seem to be directly proportional to the fruit content. Fruits are a good source of natural antioxidants such as polyphenols [45]. However, in our study, ingredients represent higher DPPH inhibition activity than final products. This can be attributed to the degradation of sensitive antioxidant compounds during processing. The number of antioxidant compounds depends on various factors, such as temperature, heat, processing parameters, solvent polarity, particle size, etc. [8]. In the present study, the major factor causing a decrease in antioxidant activity was the heat (e.g., dates soaked in hot water), as well as the smaller particle size of fruits andprocessing parameters involved. 
Table 5. Microbiological and antioxidant characteristics of high-protein bar components.

\begin{tabular}{|c|c|c|c|c|c|c|c|}
\hline \multirow{2}{*}{ Ingredients } & \multicolumn{4}{|c|}{ Count of Microorganisms $\left[\log _{10} \mathrm{CFU} / \mathrm{g}\right]$} & \multicolumn{2}{|c|}{ Presence of Microorganisms } & \multirow{2}{*}{$\begin{array}{c}\text { Antioxidant Activity } \\
{[\% \text { Inhibition of DPPH }]}\end{array}$} \\
\hline & TVC & ENT & EC & TYMC & SALM & BAC & \\
\hline Whey protein concentrate & $<1.0$ & $<1.0$ & $<1.0$ & $1.48 \pm 0.14^{\mathrm{B}}$ & - & - & $20.6 \pm 2.20^{B}$ \\
\hline Coconut flakes & $2.49 \pm 0.19 \mathrm{~A}$ & $1.85 \pm 0.22 \mathrm{~A}$ & $<1.0$ & $1.20 \pm 0.93^{\mathrm{B}}$ & - & + & $44.8 \pm 3.19 \mathrm{~A}$ \\
\hline Coconut flour & $2.49 \pm 0.27 \mathrm{~A}$ & $2.66 \pm 0.36^{\mathrm{B}}$ & $<1.0$ & $1.58 \pm 0.31^{\mathrm{B}}$ & - & + & $44.5 \pm 2.67 \mathrm{~A}$ \\
\hline Coconut oil & $1.93 \pm 0.04^{B}$ & $<1.0$ & $<1.0$ & $1.40 \pm 0.05^{\mathrm{B}}$ & - & - & $32.5 \pm 3.08^{B}$ \\
\hline Pumpkin seeds & $3.60 \pm 0.83^{C}$ & $2.11 \pm 0.06^{\mathrm{AB}}$ & $<1.0$ & $2.10 \pm 0.73^{\mathrm{A}}$ & - & - & $28.5 \pm 1.16^{\mathrm{B}}$ \\
\hline Oat flakes & $1.74 \pm 0.20^{\mathrm{B}}$ & $1.18 \pm 0.04^{\mathrm{A}}$ & $<1.0$ & $1.80 \pm 0.11 \mathrm{AB}$ & - & - & $67.3 \pm 4.14 \mathrm{C}$ \\
\hline Spelt flakes & $1.60 \pm 0.56^{\mathrm{B}}$ & $2.92 \pm 0.11^{\mathrm{B}}$ & $<1.0$ & $2.10 \pm 0.30^{\mathrm{A}}$ & - & + & $59.3 \pm 2.49^{C}$ \\
\hline Sesame & $3.41 \pm 1.08 \mathrm{AC}$ & $1.30 \pm 0.67 \mathrm{~A}$ & $<1.0$ & $1.91 \pm 0.02 \mathrm{~A}$ & - & - & $70.9 \pm 2.95^{C}$ \\
\hline Dried dates & $1.72 \pm 0.45^{\mathrm{B}}$ & $1.33 \pm 0.14^{\mathrm{A}}$ & $<1.0$ & $1.04 \pm 0.18^{\mathrm{B}}$ & - & - & $88.1 \pm 4.14^{\mathrm{D}}$ \\
\hline Raisins & $1.50 \pm 0.01^{\mathrm{D}}$ & $<1.0$ & $<1.0$ & $1.60 \pm 1.07 \mathrm{AB}$ & - & - & $73.9 \pm 1.67^{C}$ \\
\hline Goji berries & $2.41 \pm 0.72 \mathrm{AB}$ & $3.00 \pm 0.32^{B}$ & $<1.0$ & $2.14 \pm 0.12^{\mathrm{A}}$ & - & + & $98.1 \pm 3.75^{\mathrm{D}}$ \\
\hline Dried cherries & $1.54 \pm 0.15 \mathrm{BD}$ & $<1.0$ & $<1.0$ & $1.48 \pm 0.04^{\mathrm{B}}$ & - & - & $97.6 \pm 4.22 \mathrm{D}$ \\
\hline Hazelnuts & $1.54 \pm 0.43^{\mathrm{BD}}$ & $2.53 \pm 0.79 \mathrm{AB}$ & $<1.0$ & $1.54 \pm 0.74 \mathrm{AB}$ & - & + & $85.8 \pm 1.54 \mathrm{CD}$ \\
\hline Walnuts & $2.41 \pm 1.07 \mathrm{AB}$ & $1.87 \pm 0.36^{\mathrm{A}}$ & $<1.0$ & $1.74 \pm 0.03^{\mathrm{B}}$ & - & - & $74.9 \pm 3.15^{C}$ \\
\hline Peanut butter & $<1.0$ & $<1.0$ & $<1.0$ & $1.18 \pm 0.05^{\mathrm{B}}$ & - & - & $65.4 \pm 2.96^{C}$ \\
\hline Currant jam & $<1.0$ & $<1.0$ & $<1.0$ & $<1.0$ & - & - & $75.9 \pm 3.49^{C}$ \\
\hline Cherry jam & $<1.0$ & $<1.0$ & $<1.0$ & $<1.0$ & - & - & $84.1 \pm 1.16^{C D}$ \\
\hline Chokeberry jam & $<1.0$ & $<1.0$ & $<1.0$ & $<1.0$ & - & - & $77.8 \pm 3.55^{C}$ \\
\hline Cocoa & $1.15 \pm 0.06^{\mathrm{B}}$ & $<1.0$ & $<1.0$ & $<1.0$ & - & - & $89.8 \pm 4.06^{\mathrm{D}}$ \\
\hline Chocolate & $1.29 \pm 0.09^{B}$ & $<1.0$ & $<1.0$ & $1.66 \pm 0.14^{\mathrm{B}}$ & - & - & $88.4 \pm 3.82 \mathrm{D}$ \\
\hline Inulin & $1.0 \pm 0.02^{B}$ & $<1.0$ & $<1.0$ & $1.41 \pm 0.29^{B}$ & - & - & $40.1 \pm 1.46^{\mathrm{A}}$ \\
\hline Sugar cane & $<1.0$ & $<1.0$ & $<1.0$ & $<1.0$ & - & - & $25.8 \pm 3.01^{B}$ \\
\hline
\end{tabular}

Explanatory: TVC—-total viable counts, ENT—Enterobacteriaceae family bacteria, EC—Escherichia coli, TYMC—-total yeasts and molds counts, SALM-Salmonella spp., BAC—Bacillus cereus; $(+)$ - the presence of Salmonella spp./Bacillus cereus in $25 \mathrm{~g}$ of product; (-) - the absence of Salmonella spp./Bacillus cereus in $25 \mathrm{~g}$ of product; nd-not determined; Values denoted by different superscripts in the same column differ significantly $(p<0.05)$. 


\subsubsection{Water Activity and $\mathrm{pH}$ Value}

It was found that all newly developed high-protein bars were characterized by a similar $\mathrm{pH}$ value range from 6.343 to 7.013 (Table 4$)$. The most varied $(p<0.05)$ were $M$ bars $(6.793,7.013$, 6.334, respectively). The remaining types of bars ( $\mathrm{P}$ bars and $\mathrm{C}$ bars) had similar $\mathrm{pH}$ values of approximately $6.9(p>0.05)$. Intermediate-moisture foods have water activity $\left(\mathrm{a}_{\mathrm{w}}\right)$ in the range $0.6-0.9$ [46], and high-protein bars fall within this region. The water activity in the tested organic bars was various and ranged from 0.63 to 0.74 . The highest values of $a_{w}$ were detected in the case of all coconut bars as well as P2 sample $(p<0.05)$. Acidity and water activity are the factors affecting the course of biological processes, especially on the growth and development of microorganisms. Commercial protein bars presented values ranging from 0.60 to 0.65 . This value can be lowered, i.e., high-protein bars with microcapsules with casein hydrolysate represented $\mathrm{a}_{\mathrm{w}}<0.6$ are considered microbiologically stable [47].

\subsection{Microbiological Quality}

In Table 5 microbiological quality of raw material—ingredients of developed high-proteins bars are presented. All raw materials were of good microbiological quality. Low total microbial counts (below $3 \log \mathrm{CFU} / \mathrm{g}$ ) were found in almost all samples, except sesame and pumpkin seeds. A low count of the Enterobacteriaceae was also observed (spelt flakes and goji berries had the highest number: 2.92 and $3.00 \log \mathrm{CFU} / \mathrm{g}$, respectively). Escherichia coli and Salmonella spp. were not detected. A small number of yeasts and molds have been observed. In most samples Bacillus cereus species were not detected, except coconut flakes, coconut flour, spelt flakes, goji berries, and hazelnuts. Organic produce is more exposed to microbiological contamination than conventional produce and may harbor pathogenic microorganisms such as Salmonella spp., Listeria monocytogenes, and Escherichia coli $[48,49]$. Table 6 presents the results of microbiological analyses of organic high-protein bars. Fresh $\mathrm{M}$ and $\mathrm{C}$ bars were of good microbiological quality. The total number of mesophilic microflora was 3-4 log CFU/g. In the tested samples, no bacteria from the Enterobacteriaceae family, Escherichia coli and no yeasts and molds were observed. Salmonella spp. was not found, although M samples were contaminated with Bacillus cereus.

After 4 weeks of storage, the tested $\mathrm{M}$ bars were of propermicrobiological quality. A low total number of microorganisms was found in the case of storage at temperature $4{ }^{\circ} \mathrm{C}(3.70-5.11 \log \mathrm{CFU} / \mathrm{g})$, as well as at $37^{\circ} \mathrm{C}(3.30-4.51 \log \mathrm{CFU} / \mathrm{g})$. In these tests, no bacteria from the Enterobacteriaceae family, Escherichia coli, and Salmonella spp. were found. The number of yeast and molds was low ( $<3.0 \log \mathrm{CFU} / \mathrm{g}$ in case of $4{ }^{\circ} \mathrm{C}$ storage, and $<1.0 \log \mathrm{CFU} / \mathrm{g}$ in case of $37^{\circ} \mathrm{C}$ storage), but the presence of Bacillus cereus was found. The $\mathrm{P}$ bars have a slightly worse microbiological quality compared to the $\mathrm{M}$ and $\mathrm{C}$ bars. A higher total count of bacteria (over $4 \log \mathrm{CFU} / \mathrm{g}$ ) and the average count of Enterobacteriaceae was observed. Moreover, in P bars, the presence of Bacillus cereus was found, and in P1 and P2 samples Escherichia coli was observed. No yeast and molds as well as Salmonella spp. bacteria were observed in any of the tested $\mathrm{P}$ bars.The $\mathrm{P}$ bars have medium microbiological quality after 4 weeks of storage. The total number of microorganisms was $3.85 \mathrm{log}$ CFU/g in case of P1 sample to 5.34-6.58 $\log$ CFU/g in the case of P3. The microbiological changes were affected by the temperature of storage $(p<0.05)$. A low number of bacteria from the Enterobacteriaceae family was found $(<1 \log \mathrm{CFU} / \mathrm{g})$ in most cases. The number of yeasts and molds was quite high $(4.11-7.31 \log \mathrm{CFU} / \mathrm{g})$ in the case of $4{ }^{\circ}$ Cstorage and medium (2.60-4.48 $\left.\log \mathrm{CFU} / \mathrm{g}\right)$ in the case of $37^{\circ} \mathrm{C}$. The surface of the tested $\mathrm{P}$ bars showed molding, which reflected in the microbiological quality. The presence of Bacillus cereus bacteria was observed in the P1 bar samples. The best microbiological quality was $C$ bars. The total number of microorganisms was low and ranged from 3.00 to $4.85 \log \mathrm{CFU} / \mathrm{g}$, regardless of storage temperature. In all the tested samples, no bacteria from the Enterobacteriaceae family, Escherichia coli were found, and $<3 \log$ CFU/g of yeasts and molds were found. Salmonella spp. and Bacillus cereus was not observed. 
Microbiological quality of tested organic high-protein bars can be considered as proper. However, after storage total yeasts and molds increased in almost all samples, and the changes were higher in case of chilled storage, probably because of higher humidity. Moreover, all samples were stored in an oxygen atmosphere, which could promote the growth of these microorganisms in tested samples. To eliminate or minimize the growth of total yeasts and molds counts (TYMC), vacuum or modified atmosphere packaging should be applied.

Table 6. Microbiological analyses of high-protein bars.

\begin{tabular}{|c|c|c|c|c|c|c|}
\hline \multirow{2}{*}{ Bar Symbol } & \multicolumn{4}{|c|}{ Count of Microorganisms $\left[\log _{10} \mathrm{CFU} / \mathrm{g}\right]$} & \multicolumn{2}{|c|}{ Presence of Microorganisms } \\
\hline & TVC & ENT & EC & TYMC & SALM & BAC \\
\hline \multicolumn{7}{|c|}{ Fresh Samples-After Production Process (0 time) } \\
\hline M1 & $3.60 \pm 1.02 \mathrm{~A}$ & $<1.0$ & $<1.0$ & $<1.0$ & - & + \\
\hline M2 & $3.48 \pm 0.89^{\mathrm{A}}$ & $<1.0$ & $<1.0$ & $<1.0$ & - & + \\
\hline M3 & $4.00 \pm 0.25^{\mathrm{A}}$ & $<1.0$ & $<1.0$ & $<1.0$ & - & + \\
\hline P1 & $4.48 \pm 0.27 \mathrm{AB}$ & $3.15 \pm 0.45^{\mathrm{A}}$ & $2.60 \pm 0.29^{\mathrm{A}}$ & $<1.0$ & - & + \\
\hline $\mathrm{P} 2$ & $4.85 \pm 0.43^{\mathrm{B}}$ & $2.60 \pm 0.92^{\mathrm{A}}$ & $2.00 \pm 0.33^{A}$ & $<1.0$ & - & + \\
\hline P3 & $4.48 \pm 0.68^{\mathrm{AB}}$ & $2.78 \pm 0.84^{\mathrm{A}}$ & $<1.0$ & $<1.0$ & - & + \\
\hline $\mathrm{C} 1$ & $3.90 \pm 0.75^{\mathrm{A}}$ & $<1.0$ & $<1.0$ & $<1.0$ & - & - \\
\hline $\mathrm{C} 2$ & $3.57 \pm 1.06^{\mathrm{A}}$ & $<1.0$ & $<1.0$ & $<1.0$ & - & - \\
\hline $\mathrm{C} 3$ & $3.26 \pm 1.11^{\mathrm{A}}$ & $<1.0$ & $<1.0$ & $<1.0$ & - & - \\
\hline \multicolumn{7}{|c|}{ Chilled $\left(4^{\circ} \mathrm{C}\right)$ Samples (4 weeks) } \\
\hline M1 & $3.78 \pm 0.81^{\mathrm{A}}$ & $<1.00$ & $<1.00$ & $2.30 \pm 0.09 \mathrm{~A}$ & - & + \\
\hline M2 & $5.11 \pm 1.19^{B}$ & $<1.00$ & $<1.00$ & $2.30 \pm 0.15^{\mathrm{A}}$ & - & + \\
\hline M3 & $3.70 \pm 0.62^{\mathrm{A}}$ & $<1.00$ & $<1.00$ & $2.48 \pm 0.21^{\mathrm{A}}$ & - & + \\
\hline P1 & $3.85 \pm 0.84^{\mathrm{A}}$ & $<1.00$ & $<1.00$ & $4.11 \pm 0.69^{\mathrm{B}}$ & - & + \\
\hline P2 & $6.30 \pm 1.22^{C}$ & $2.00 \pm 0.54^{\mathrm{A}}$ & $<1.00$ & $7.31 \pm 1.51^{\mathrm{C}}$ & - & - \\
\hline P3 & $6.58 \pm 0.73^{C}$ & $2.70 \pm 0.19^{\mathrm{A}}$ & $<1.00$ & $\begin{array}{c}5.30 \pm 0.48 \\
\mathrm{BC}\end{array}$ & - & - \\
\hline $\mathrm{C} 1$ & $3.00 \pm 0.39^{\mathrm{A}}$ & $<1.00$ & $<1.00$ & $2.00 \pm 0.27^{\mathrm{A}}$ & - & - \\
\hline $\mathrm{C} 2$ & $3.60 \pm 0.92^{\mathrm{A}}$ & $<1.00$ & $<1.00$ & $<1.00$ & - & - \\
\hline $\mathrm{C} 3$ & $4.85 \pm 0.54^{\mathrm{B}}$ & $<1.00$ & $<1.00$ & $<1.00$ & - & - \\
\hline \multicolumn{7}{|c|}{ Thermostat $\left(37^{\circ} \mathrm{C}\right)$ Samples (4 weeks) } \\
\hline M1 & $4.00 \pm 1.04 \mathrm{AB}$ & $<1.00$ & $<1.00$ & $<1.00$ & - & - \\
\hline M2 & $4.51 \pm 0.68^{\mathrm{AB}}$ & $<1.00$ & $<1.00$ & $<1.00$ & - & + \\
\hline M3 & $3.30 \pm 0.51^{\mathrm{A}}$ & $<1.00$ & $<1.00$ & $<1.00$ & - & + \\
\hline P1 & $3.85 \pm 0.47^{\mathrm{A}}$ & $<1.00$ & $<1.00$ & $2.60 \pm 0.57^{\mathrm{A}}$ & - & + \\
\hline $\mathrm{P} 2$ & $4.30 \pm 0.81 \mathrm{AB}$ & $<1.00$ & $<1.00$ & $2.70 \pm 1.08^{\mathrm{A}}$ & - & - \\
\hline P3 & $5.34 \pm 0.29 \mathrm{BC}$ & $<1.00$ & $<1.00$ & $4.48 \pm 1.16^{\mathrm{B}}$ & - & - \\
\hline $\mathrm{C} 1$ & $4.52 \pm 0.93 \mathrm{AB}$ & $<1.00$ & $<1.00$ & $2.60 \pm 0.95^{\mathrm{A}}$ & - & - \\
\hline $\mathrm{C} 2$ & $3.70 \pm 0.72^{\mathrm{A}}$ & $<1.00$ & $<1.00$ & $<1.00$ & - & - \\
\hline $\mathrm{C} 3$ & $3.90 \pm 0.63^{\mathrm{A}}$ & $<1.00$ & $<1.00$ & $2.00 \pm 0.88^{\mathrm{A}}$ & - & - \\
\hline
\end{tabular}

Explanatory: musli bars (M1—with raisins, M2—with nuts, M3—with goji berries), pumpkin bars (P1—basic, P2 - with nuts, P3 - with cocoa), and coconut bars (C1 - with currant jam, C2 - with cherry jam, C3 - with chokecherry jam); TVC—-total viable counts, ENT_Enterobacteriaceae family bacteria, EC—Escherichia coli, TYMC—-total yeasts and molds counts, SALM-Salmonella spp., BAC—Bacillus cereus; $(+)$ - the presence of Salmonella spp./Bacillus cereus in $25 \mathrm{~g}$ of product; (-) - the absence of Salmonella spp./Bacillus cereus in $25 \mathrm{~g}$ of product; Values denoted by different superscripts in the same column differ significantly $(p<0.05)$.

Other researchers showed very good microbiological quality (total coliforms, yeasts, and molds count $<5.0 \times 10^{1} \mathrm{CFU} / \mathrm{g}$ ) in high-protein diet bars with the addition of chia grain [39], but the ingredients were not from organic production. On the other hand, Munshi et al. [50] have found the high number of aerobic mesophilic count $\left(8.4 \times 10^{3} \mathrm{CFU}\right)$ and $3.6 \times 10^{1} \mathrm{CFU}$ of yeasts and molds counts per gram of multi-nutrient bar developed from food ingredients of plant origin designed for improving the bone health of postmenopausal women. 
The presence of Bacillus cereus in some ingredients, as well as M and P bars in the present study, could be dangerous because of the possibility of spore-forming, which contributes to the survival of the bacteria during food processing treatments. A diversity of foods that have reported B. cereus includes honey [51], cocoa [52], vegetables, nuts and fruits [53], wheat, rice, and flour [51,54]. Furthermore, the results of Lee et al. [55] indicated a high prevalence but low count of Bacillus spp. and B. cereus in the ready-to-eat cereals products. Most studies reported a low level of B. cereus; however, the possibility of cross-contamination may occur and increase the diversity of $B$. cereus during the food processing matrix and foods.

\subsection{Sensory Quality and Consumer Acceptance}

Food quality embraces sensory attributes that are perceived by the human senses, as well as hidden attributes, such as nutritionand safety, that require sophisticated instrumentation to measure. Thus, quality can be defined as human construct for a product comprising selected properties and characteristics [56]. Sensory evaluation of high-protein organic bars was carried out directly after the production process. The results of this assessment are presented in Figures 1-3.

The $\mathrm{M}$ bars (Figure 1) were characterized by the intensity of the sensation of grain and nutty odor at the level of approximately 5 c.u. The intensity of the flavor was noted: cereal (at approximately 6 c.u.); nut and salty (at approximately 4 c.u.). Overall quality was noted at the level of 6.8-7.2 c.u. PCA analysis (Supplementary Materials, Figure S1) showed that in the case of M2 vector direction of grain flavor vs. overall quality allow the conclusion that they were positively correlated with the latter. The greatest negative impact on the overall sensory quality was caused by bitter flavor (M1) and smoothness (M2 and M3). The M bars were sticky, less smooth, and harder in consistency compared to the evaluated versions of $\mathrm{C}$ and $\mathrm{P}$ bars. Many authors indicate that there is a strong correlation between hardness and water activity $[37,46,57]$. In the present study, $\mathrm{M}$ bars had the lowest water activity, which is with an agreement with mentioned above observations.
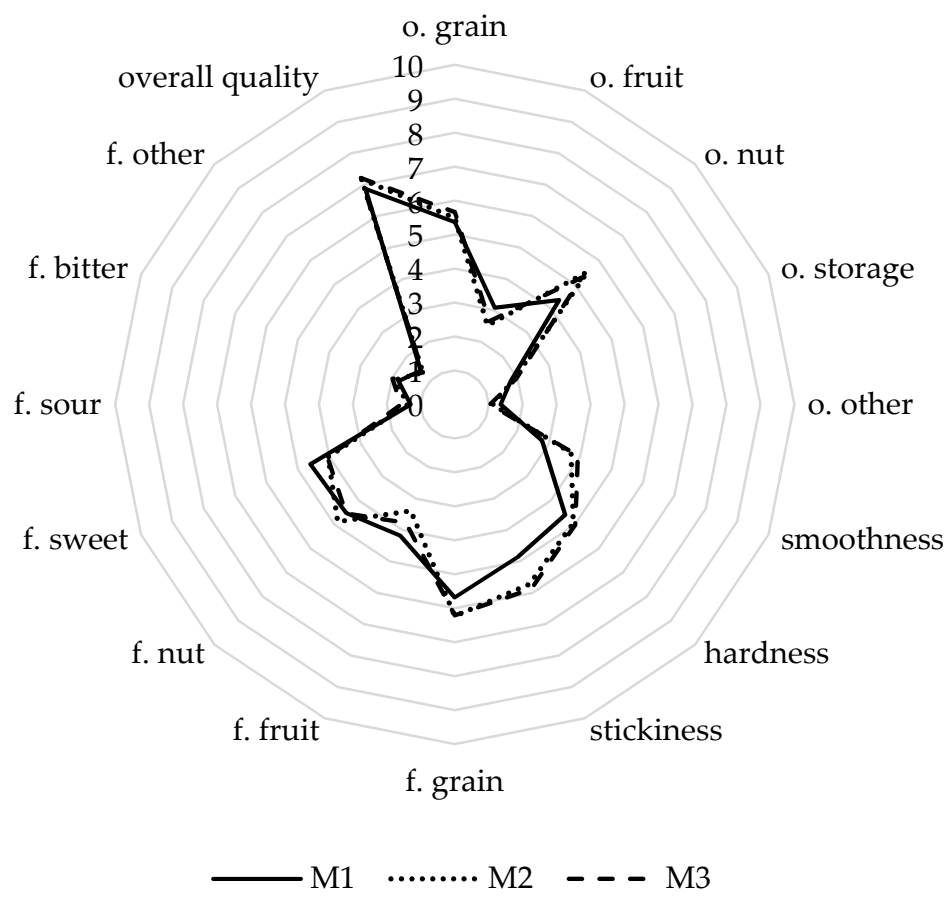

Figure 1. Results of sensory evaluation of fresh musli bars (Quantitative Descriptive Profile (QDP) method), $n=10$. Explanatory: musli bars (M1-with raisins, M2-with nuts, M3-with goji berries); o.- odor, f.-flavor. 
There was no significant differentiation between the 3 variants of $\mathrm{P}$ bars (Figure 2) in the intensity of sensation of individual sensory quality parameters $(p>0.05)$. The bars were characterized by high intensity of taste and cocoa flavor. The P bars were smooth, sticky, and soft in consistency, with a slight intensity of the sensation of bitter, flour, or sour taste. All products obtained high marks of the overall quality indicator (over 7.5-8.4 c.u.). The PCA analysis (Supplementary Materials, Figure S2) showed that in the case of P1 smoothness was positively correlated with the overall quality. However, the greatest negative impact on the overall sensory quality was caused by hardness (P1), other flavor (P2), and stickiness (P3).

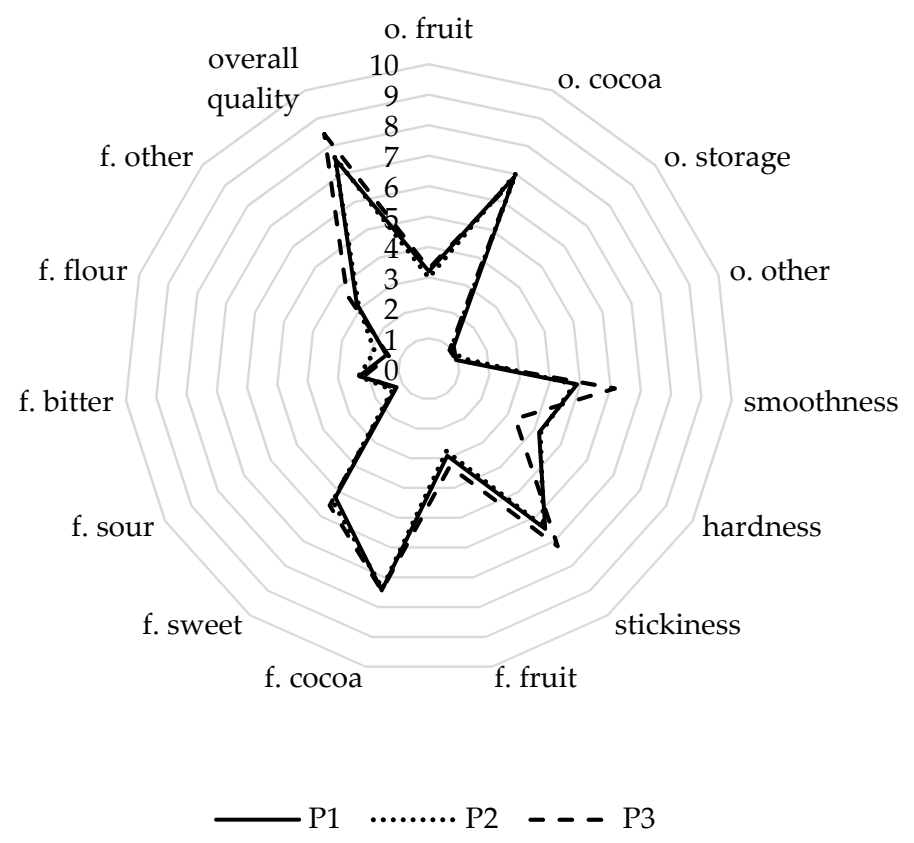

Figure 2. Results of sensory evaluation of fresh pumpkin bars (QDP method), $n=10$. Explanatory: pumpkin bars (P1—basic, P2—with nuts, P3—with cocoa); o.—odor, f.-flavor.

The $\mathrm{C}$ bars were also varied in terms of the intensity of the aroma and fruity taste sensation (Figure 3$)$. The highest intensity $(p<0.05)$ of these sensory quality parameters was recorded in the case of the $\mathrm{C} 3$ bar. All of the bars got high marks of the overall quality indicator (above 7.3 c.u.). The highest marks $(p<0.05)$ of the overall quality among all evaluated products were obtained by the sample variant C3 (9.4 c.u.). The PCA analysis (Supplementary Materials, Figure S3) showed that the greatest positive impact on the overall sensory quality was caused by fruit flavor (C1), coconut, fruit, cocoa flavor (C2), and smoothness (C3). On the other hand, the greatest negative impact on the overall sensory quality was caused by hardness and stickiness (C1), smoothness (C2), and other odor and flavor (C3).

The sense of the intensity of flavors in the evaluated bars was related to the applied raw material composition. Therefore, characteristics such as odor, flavor, consistency, and overall quality are essential in the development of new products. Protein enrichment of bars may cause changes in the sensory evaluation of these products. In addition to smell and taste, the texture is one of the most important distinguishing features. High levels of protein in bars may result in the hardening of bars. The physicochemical changes occurring in the bars are mainly caused by water loss during storage $[46,57]$. However, the use of whey protein concentrate was found to maintain a softer bar texture over time but can be accompanied by a bitter flavor [37].

In the present study, $\mathrm{C}$ bars were softer and had the highest marks of the overall quality, Moreover, these bars contained more than $20 \%$ of protein. Based on the obtained results of sensory evaluation, one product was finally selected for use in consumer research. The highest scores of overall quality were recorded in the case of the P3 sample (8.4 c.u.) and C3 sample (9.4 c.u.). However, the results 
of the microbiological quality and protein content had a decisive influence on the selection of the C3 sample for consumer tests.

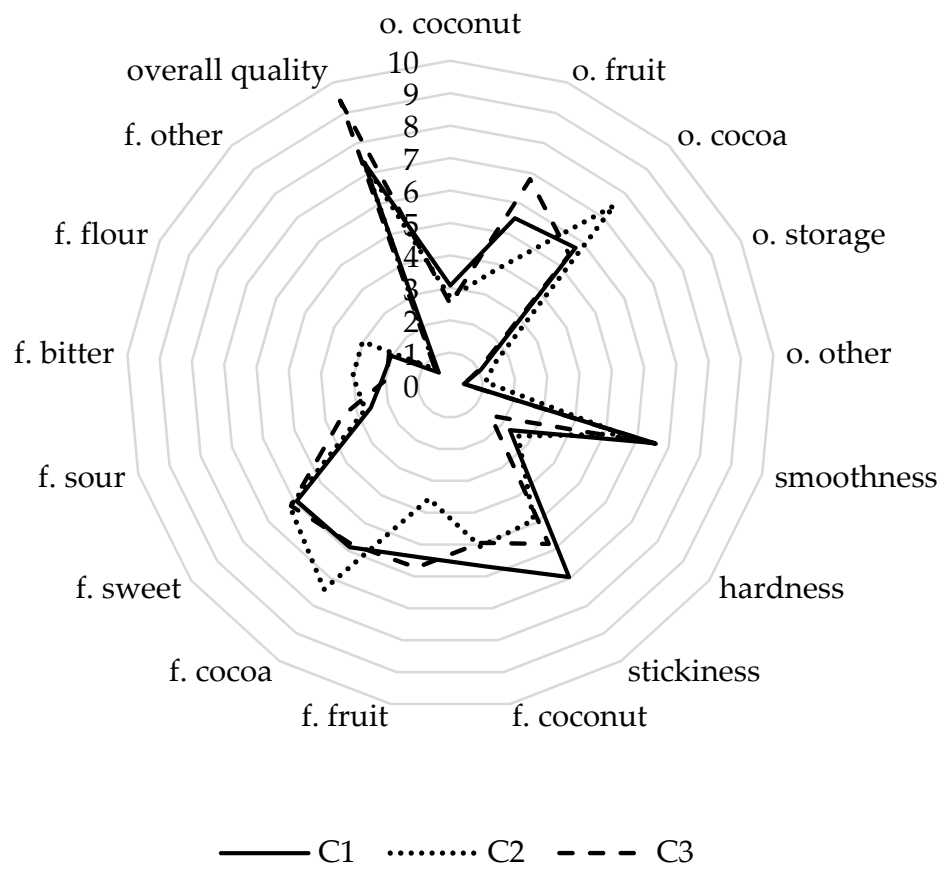

Figure 3. Results of sensory evaluation of fresh coconut bars (QDP method), $n=10$. Explanatory: coconut bars (C1with currant jam, C2-with cherry jam, C3-with chokecherry jam); o.-odor, f.-flavor.

In total, a group of $78 \%$ of all respondents participating in the survey assessed this product as "very desirable" and "desirable". The product scored 6 and below, in the case of $13 \%$ of all respondents. In another study [8], newly developed date bars were assessed and the authors have found that overall acceptance was low (3.7-3.8 with 7-point hedonic scale). In similar studies, ahigh-protein diet bar with chia was evaluated [39]. This product responded to the expectations of consumers concerning organoleptic requirements and most people intended to buy such a product.

The consumer tests, in the present study, showed that over $73 \%$ of respondents buy organic food and know the offer of high-protein products available on the market. Moreover, $52 \%$ of consumers claimed that they buy such products occasionally. About $26 \%$ of respondents stock up on high-protein products 2-3 times a week. Over $90 \%$ of all respondents declare that they pay attention to their diet, and $70 \%$ of all consumers are people who play sport. More than $93 \%$ of consumers declared that they would buy such a product if it was available on the market. The appropriate price for the assessed organic bar according to $78 \%$ of all responders is the amount $<1 €$. Many authors confirm that a gap exists between favorable attitudes and intentions on the one hand and actual purchase on the other hand [58,59]. As major barriers, they introduce economic reasons that are expressed to further purchase behavior. Research observes that positive consumers' purchase behavior to organic food occurs primarily among the more wealthy consumers [60]. Other factors are: economic background, price consciousness, and sensitivity, the trade-off between price and value, and willingness to pay [59]. Pricing of organic food is a multifaceted and even paradoxical issue because consumers desire low prices but, at the same time, might interpret low prices as a cue of undesirably low quality [61].

\section{Conclusions}

The results of the research have shown that it is possible to develop the high-protein bars using organic whey protein and plant origin raw materials. The novelty of the developed products in comparison with others available on the market is thatthey can beconsidered as concentrated, functional 
food products with a high nutritional value, proper microbiological quality, and sensory acceptance. The bars exhibited the appropriate level of energy and nutritional benefits, such as polyunsaturated fatty acids as well as a high fiber content $(>7 \mathrm{~g} / 100 \mathrm{~g})$ and high total protein level. The protein content was dependent on the product composition. Musli (M) and coconut (C) bars contained an appreciable amount of proteins in total (over $20 \mathrm{~g} / 100 \mathrm{~g}$ ), in comparison, pumpkin (P) bars contained less protein (17.3-19.1 g/100 g). These novel products provide a good amount of nutrients that can meet the terms of daily nutritional requirements for an individual.

All developed bars were characterized by the high scavenging capacity of DPPH free radicals. The highest values of antioxidant activity were observed in coconut bars (75.2-77.1\%), whereas musli and pumpkin bars showed moderate activity (61.0-69.3\% and 54.1-69.3\%, respectively). The antioxidant abilities of the tested products were directly proportional to the fruit content. It can be stated that the developed bars have high antioxidant properties that are important from a nutritional point of view.

Attention should be paid to some restrictions resulting from the use of organic raw materials. They result from greater microbiological contamination of these raw materials. Some organic ingredients were contaminated with Bacillus cereus, and these bacteria were also found in musli and pumpkin bars.

Water activity and $\mathrm{pH}$ values also indicated the potential for microorganism growth during the storage of bars. This gives the possibility of growth to a wide group of spoilage microorganisms including yeasts, molds, and proteolytic ones. Future studies should be focused to optimize the shelf life condition and storage tests in purpose to eliminate or minimize the microbiological contamination and specify the date of expiration.

The sensory quality of products is the basis for their acceptance by consumers. Flavors additives had a significant influence on the overall quality of bars. The $\mathrm{C} 3$ coconut bar sample has found consumer's acceptance because was soft, smooth, easy to bite and chew, which give the possibility to use it in a wide group of people's diet. The newly developed high-protein products have features that proved they can be a quick snack before or after physical activity or replacement for lunch. Due to the composition and nutritional value, they can be used in the rational nutrition of people who care about their health to enrich one's daily meal plan.

Supplementary Materials: The following are available online at http://www.mdpi.com/2077-0472/10/9/390/s1, Figure S1: Principal component analysis graphs of the sensory evaluation of M1-M3; Figure S2: Principal component analysis graphs of the sensory evaluation of P1-P3; Figure S3: Principal component analysis graphs of the sensory evaluation of C1-C3; Table S1: Descriptors and the marks of anchors defined in the QDP; Table S2: Consumer assessment of organic high-protein bar-questions and responses; Table S3: Total protein concentration and amino acids profile in whey protein concentrate and high-protein bars.

Author Contributions: Conceptualization, D.Z. and D.K.-K.; methodology, A.S., D.Z., A.E., M.T., and K.N.-S.; software, A.S. and D.Z.; validation, A.Ł. and A.S.; formal analysis, D.K.-K.; investigation, A.S., D.Z., A.Ł., M.T., and K.N.-S.; resources, A.S., D.Z., and A.E.; data curation, A.S. and D.Z.; writing-original draft preparation, A.S. and D.Z.; writing-review and editing, A.Ł., A.S., M.T., K.N.-S., and D.K.-K.; visualization, D.Z.; supervision, D.Z. and D.K.-K.; project administration, D.K.-K.; funding acquisition, D.K.-K. All authors have read and agreed to the published version of the manuscript.

Funding: This research was funded by MINISTRY OF AGRICULTURE AND RURAL DEVELOPMENT (decision No. HOR.re.027.6.2017) from a subsidy for organic farming research entitled: Processing of plant and animal products with organic methods: Research on optimization and development of innovative processing solutions to increase the value of healthy organic products. The APC was funded by the Institute of Human Nutrition Sciences, Warsaw University of Life Sciences (WULS).

Conflicts of Interest: The authors declare no conflict of interest.

\section{References}

1. Miraballes, M.; Fiszman, S.; Gámbaro, A.; Varela, P. Consumer perceptions of satiating and meal replacement bars, built up from cues in packaging information, health claims and nutritional claims. Food Res. Int. 2014, 64, 456-464. [CrossRef] [PubMed]

2. The World's Largest Market Research Store. Available online: www.researchandmarkets.com (accessed on 21 June 2020). 
3. Commission Directive 96/8/EC of 26 February 1996 on Foods Intended for use in Energy Restricted Diets for Weight Reduction; European Union: Brussels, Belgium, 1996.

4. Regulation (EC) No 1924/2006 of the European Parliament and of the Council of 20 December 2006 on Nutrition and Health Claims Made on Foods; European Union: Brussels, Belgium, 2006.

5. Brown, E.C.; DiSilvestro, R.A.; Babaknia, A.; Devor, S.T. Soy versus whey protein bars: Effects on exercise training impact on lean body mass and antioxidant status. Nutr. J. 2004, 3, 22. [CrossRef] [PubMed]

6. Harwood, W.S.; Drake, M. Understanding implicit and explicit consumer desires for protein bars, powders, and beverages. J. Sens. 2019, 34, 12493. [CrossRef]

7. Gulati, S.; Misra, A.; Tiwari, R.; Sharma, M.; Pandey, R.M.; Yadav, C.P. Effect of high-protein meal replacement on weight and cardiometabolic profile in overweight/obese Asian Indians in North India. Br. J. Nutr. 2017, 117, 1531-1540. [CrossRef]

8. Parn, O.J.; Bhat, R.; Yeoh, T.K.; Al-Hassan, A.A. Development of novel fruit bars by utilizing date paste. Food Biosci. 2015, 9, 20-27. [CrossRef]

9. Luik, A.; Pehme, S.; Matt, D.; Peetsmann, E.; Rembialkowska, E. Quality of Organic vs. Conventional Food and Effects on Health: Report; Estonian University of Life Sciences: Tartu, Estonian, 2011.

10. Huber, M.; Rembiałkowska, E.; Średnicka, D.; Bügel, S.; Van De Vijver, L.P.L. Organic food and impact on human health: Assessing the status quo and prospects of research. NJAS-Wagening. J. Life Sci. 2011, 58, 103-109. [CrossRef]

11. Popa, M.E.; Mitelut, A.C.; Popa, E.E.; Stan, A.; Popa, V.I. Organic foods contribution to nutritional quality and value. Trends Food Sci. Technol. 2019, 84, 15-18. [CrossRef]

12. Vigar, V.; Myers, S.; Oliver, C.; Arellano, J.; Robinson, S.; Leifert, C.A. Systematic Review of Organic Versus Conventional Food Consumption: Is There a Measurable Benefit on Human Health? Nutrients 2020, $12,7$. [CrossRef]

13. Baudry, J.; Péneau, S.; Allès, B.; Touvier, M.; Hercberg, S.; Galan, P.; Amiot, M.J.; Lairon, D.; Mejean, C.; Kesse-Guyot, E. Food choice motives when purchasing in organic and conventional consumer clusters: Focus on sustainable concerns (The NutriNet-Santé Cohort Study). Nutrients 2017, 9, 88. [CrossRef]

14. Giudici, K.V.; Baudry, J.; Méjean, C.; Lairon, D.; Bénard, M.; Hercberg, S.; Bellisle, F.; Kesse-Guyot, E.; Péneau, S. Cognitive Restraint and History of Dieting Are Negatively Associated with Organic Food Consumption in a Large Population-Based Sample of Organic Food Consumers. Nutrients 2019, 11, 2468. [CrossRef]

15. AOAC. Determination of Protein Content in Food, Method 945.18-B. In Official Methods of Analysis; AOAC International Publisher: Gaithersburg, MD, USA, 2005.

16. AOAC International. 994.12 Official Methods of Analysis Amino Acids Analysis Feed (OPA Post Column)—Item 81 (4.1.11); 985.28 Official Method Sul fur Amino Acids in Food, Feed Ingredients, and Processed Foods. (45.4.05); 934.06 Official Methods of Analysis Proximate Analysis and Calculations Moisture (M) Fruits, Vegetables, and Their Products-Item 107. (37.1.10); 923.03 Official Methods of Analysis Proximate Analysis and Calculations Ash Determination (Ash) Flour-Item 49. (32.1.05 or 14.006); 985.29 Official Methods of analysis Proximate Analysis and Calculations Total Dietary Fiber (TDF) in Foods-Item 7. Reference Data: Method (45.4.07); 920.39 Official Methods of Analysis Proximate Analysis and Calculations Crude Fat (CF)_Item 17; Association of Analytical Communities: Gaithersburg, MD, USA, 2006.

17. Provision of Food Information to Consumers. Commission Regulation (EU) No. 1169/2011 of the European Parliament and of the Council of 25 October 2011; European Union: Brussels, Belgium, 2011.

18. International Organization for Standarization. ISO 12966-2: Animal and Vegetable Fats and Oils-Gas Chromatography of Fatty acid Methyl Esters_Part 2: Preparation of Methyl Esters of Fatty Acids; ISO: Geneva, Switzerland, 2017.

19. International Organization for Standarization. ISO 12966-1:2014/AC: Animal and Vegetable fats and oils - Gas Chromatography of Fatty Acid Methyl Esters_Part 1: Guidelines on Modern gas Chromatography of Fatty Acid Methyl Esters; ISO: Geneva, Switzerland, 2015.

20. Brand-Williams, W.; Cuvelier, M.E.; Berset, C.L.W.T. Use of a free radical method to evaluate antioxidant activity. LWT Food Sci. Technol. 1995, 28, 25-30. [CrossRef]

21. Alothman, M.; Bhat, R.; Karim, A.A. UV radiation-induced changes of antioxidant capacity of fresh-cut tropical fruits. Innov. Food Sci. Emerg. Technol. 2009, 10, 512-516. [CrossRef] 
22. Polish Committee for Standardization (Polski Komitet Normalizacyjny). PN-79/A-88024 Hard Confection Products—Determination of Acidity; PKN: Warsaw, Poland, 1979.

23. International Organization for Standarization. ISO 18787:2017 Foodstuffs-Determination of Water Activity; ISO: Geneva, Switzerland, 2017.

24. International Organization for Standarization. ISO 4833-2:2013 Microbiology of the Food Chain-Horizontal Method for the Enumeration of Microorganisms_Part 2: Colony Count at 30 Degrees C by the Surface Plating Technique; ISO: Geneva, Switzerland, 2013.

25. International Organization for Standarization. ISO 21528-2:2017 Microbiology of the Food Chain-Horizontal Method for the Detection and Enumeration of Enterobacteriaceae_-Part 2: Colony-Count Technique; ISO: Geneva, Switzerland, 2017.

26. International Organization for Standarization. ISO 21527-1:2008 Microbiology of Food and Animal Feeding Stuffs-Horizontal Method for the Enumeration of Yeasts and Moulds-Part 1: Colony Count Technique in Products with Water Activity Greater than 0.95; ISO: Geneva, Switzerland, 2008.

27. International Organization for Standarization. ISO 21527-2:2008 Microbiology of Food and Animal Feeding Stuffs-Horizontal Method for the Enumeration of yeasts and moulds_Part 2: Colony Count Technique in products with Water Activity Less Than or Equal to 0.95; ISO: Geneva, Switzerland, 2008.

28. International Organization for Standarization. ISO 16649-2:2001 Microbiology of food and Animal Feeding Stuffs-Horizontal Method for the Enumeration of beta-Glucuronidase-Positive Escherichia coli-Part 2: Colony-Count Technique at 44 Degrees C Using 5-bromo-4-chloro-3-Indolyl beta-D-Glucuronide; ISO: Geneva, Switzerland, 2001.

29. International Organization for Standarization. ISO 21871:2006 Microbiology of Food and Animal Feeding Stuffs-Horizontal Method for the Determination of Low Numbers of Presumptive Bacillus cereus—Most Probable Number Technique and Detection Method; ISO: Geneva, Switzerland, 2006.

30. International Organization for Standarization. ISO 6579-1:2017 Microbiology of the Food Chain-Horizontal Method for the Detection, Enumeration and Serotyping of Salmonella_Part 1: Detection of Salmonella spp.; ISO: Geneva, Switzerland, 2017.

31. International Organization for Standarization. ISO 13299:2016 Sensory analysis-Methodology-General Guidance for Establishing a Sensory Profile; ISO: Geneva, Switzerland, 2016.

32. Peryam, D.R.; Pilgrim, F.J. Hedonic scale method of measuring food preferences. Food Technol. 1957, 11, 9-14.

33. U.S. Department of Agricultural, Agricultural Research Service. USDA National Nutrient Database for Standard Reference, Release 28; USDA: Washington, DC, USA, 2016.

34. Riccardi, G.; Giacco, R.; Rivellese, A.A. Dietary fat, insulin sensitivity and the metabolic syndrome. Clin. Nutr. 2004, 23, 447-456. [CrossRef]

35. Rodrigues, H.G.; Vinolo, M.A.; Magdalon, J.; Fujiwara, H.; Cavalcanti, D.M.; Farsky, S.H.; Calder, P.C.; Hatanaka, E.; Curi, R. Dietary free oleic and linoleic acid enhances neutrophil function and modulates the inflammatory response in rats. Lipids 2010, 45, 809-819. [CrossRef]

36. Saini, R.K.; Keum, Y.S. Omega-3 and omega-6 polyunsaturated fatty acids: Dietary sources, metabolism, and significance: A review. Life Sci. 2018, 203, 255-267. [CrossRef]

37. Hogan, S.A.; Chaurin, V.; O'Kennedy, B.T.; Kelly, P.M. Influence of dairy proteins on textural changes in high-protein bars. Int. Dairy J. 2012, 26, 58-65. [CrossRef]

38. McMahon, D.J.; Adams, S.L.; McManus, W.R. Hardening of High-Protein Nutrition Bars and Sugar/Polyol-Protein Phase Separation. J. Food Sci. 2009, 74, E312-E321. [CrossRef]

39. Veggi, N.; Voltarelli, F.A.; Pereira, J.M.N.; Silva, W.C.; Navalta, J.W.; Cavenaghi, D.F.L.D.C.; Barros, W.M.D. Quality of high-protein diet bar plus chia (Salvia hispanica L.) grain evaluated sensorially by untrained tasters. Food Sci. Technol. 2018, 38, 306-312. [CrossRef]

40. Ha, E.; Zemel, M.B. Functional properties of whey, whey components, and essential amino acids: Mechanisms underlying health benefits for active people. J. Nutr. Biochem. 2003, 14, 251-258. [CrossRef]

41. Sawaya, W.N.; Khatchadourian, H.A.; Khalil, J.K.; Mashadi, A.S. Processing of three major Saudi Arabian date cultivars into Jam. J. Food Sci. Technol. 1983, 20, 149-152.

42. Maurer, G.; Fukuda, G.; Nielsen, S. Development of bean-based granola bars and cereal. Cereal Foods World 2005, 50, 27-32.

43. O'Keefe, S.; Bianch, L.; Sharman, J. Soybean Nutrition. SM J. Nutr. Metabol. 2015, 1, 1006.

44. Spotti, M.J.; Campanella, O.H. Functional Modifications by Physical Treatments of Dietary Fibers used in Food Formulations. Curr. Opin. Food Sci. 2017, 15, 70-78. [CrossRef] 
45. Xu, D.P.; Li, Y.; Meng, X.; Zhou, T.; Zhou, Y.; Zheng, J.; Li, H.B. Natural antioxidants in foods and medicinal plants: Extraction, assessment and resources. Int. J. Mol. Sci. 2017, 18, 96. [CrossRef] [PubMed]

46. Loveday, S.M.; Hindmarsh, J.P.; Creamer, L.K.; Singh, H. Physicochemical changes in intermediate-moisture protein bars made with whey protein or calcium caseinate. Food Res. Int. 2010, 43, 1321-1328. [CrossRef]

47. Rocha, G.A.; Trindade, M.A.; Netto, F.M.; Fávaro-Trindade, C.S. Microcapsules of a casein hydrolysate: Production, characterization, and application in protein bars. Food Sci. Technol. Int. 2009, 15, 407-413. [CrossRef]

48. Johannessen, G.S.; Froseth, R.B.; Solemdal, L.; Jarp, J.; Wasteson, Y.; Rorvik, L.M. Influence of bovine manure as fertilizer on the bacteriological quality of organic Iceberg lettuce. J. Appl. Microbiol. 2004, 96, 787-794. [CrossRef]

49. Maffei, D.F.; de ArrudaSilveira, N.F.; Catanozi, M.D.P.L.M. Microbiological quality of organic and conventional vegetables sold in Brazil. Food Control 2013, 29, 226-230. [CrossRef]

50. Munshi, R.; Kochhar, A.; Kaur, A. Nutrient selection and optimization to formulate a nutrient bar stable on storage and specific to women at risk of osteoporosis. J. Food Sci. Technol. 2020, 57, 3099-3107. [CrossRef]

51. Iurlina, M.O.; Saiz, A.I.; Fuseli, S.R.; Fritz, R. Prevalence of Bacillus spp. in different food products collected in Argentina. LWT Food Sci. Technol. 2006, 39, 105-110. [CrossRef]

52. TeGiffel, M.C.; Beumer, R.R.; Leijendekkers, S.; Rombouts, F.M. Incidence of Bacillus cereus and Bacillus subtilis in foods in the Netherlands. Food Microbiol. 1996, 13, 53-58. [CrossRef]

53. Becker, H.; Schaller, G.; von Wiese, W.; Terplan, G. Bacillus cereus in infant foods and dried milk products. Int. J. Food Microbiol. 1994, 23, 1-15. [CrossRef]

54. Sarrıas, J.A.; Valero, M.; Salmerón, M.C. Enumeration, isolation and characterization of Bacillus cereus strains from Spanish raw rice. Food Microbiol. 2002, 19, 589-595. [CrossRef]

55. Lee, H.Y.; Chai, L.C.; Tang, S.Y.; Jinap, S.; Ghazali, F.M.; Nakaguchi, Y.; Son, R. Application of MPN-PCR in biosafety of Bacillus cereussl for ready-to-eat cereals. Food Control 2009, 20, 1068-1071. [CrossRef]

56. Jha, S.N. Food Safety and Quality. In Rapid Detection of Food Adulterants and Contaminants_Theory and Practice; Jha, S.N., Ed.; Elsevier: Amsterdam, The Netherlands, 2016.

57. Loveday, S.M.; Hindmarsh, J.P.; Creamer, L.K.; Singh, H. Physicochemical changes in a model protein bar during storage. Food Res. Int. 2009, 42, 798-806. [CrossRef]

58. GMA/Deloitte. Finding the Green in Today's Shoppers: Sustainability Trends and New Shopper Insights; Grocery Manufacturers Association and Deloitte: Washington, DC, USA, 2009. Available online: http://www. gmaonline.org/downloads/research-and-reports/greenshopper09.pdf (accessed on 25 April 2020).

59. Aschemann-Witzel, J.; Zielke, S. Can't buy me green? A review of consumer perceptions of and behavior toward the price of organic food. J. Consum. Aff. 2017, 51, 211-251. [CrossRef]

60. Thøgersen, J. Green Shopping: For Selfish Reasons or the Common Good? Am. Behav. Sci. 2011, 55, 1052-1076. [CrossRef]

61. Hughner, R.S.; McDonagh, P.; Prothero, A.; Shultz, C.J.; Stanton, J. Who Are Organic Food Consumers? A Compilation and Review of Why People Purchase Organic Food. J. Consum. Behav. 2007, 62, 94-110. [CrossRef]

(C) 2020 by the authors. Licensee MDPI, Basel, Switzerland. This article is an open access article distributed under the terms and conditions of the Creative Commons Attribution (CC BY) license (http://creativecommons.org/licenses/by/4.0/). 